

Scand J Work Environ Health 1994;20(2):93-100

https://doi.org/10.5271/sjweh.1415

Issue date: 01 Apr 1994

Hearing loss and handicap of professional soldiers exposed to gunfire noise.

by Ylikoski ME, Ylikoski JS

Affiliation: Lappeenranta Regional Institute of Occupational Health, Finland.

This article in PubMed: www.ncbi.nlm.nih.gov/pubmed/8079140

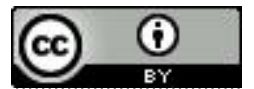




\title{
Hearing loss and handicap of professional soldiers exposed to gunfire noise
}

\author{
by Matti E Ylikoski, MD, ${ }^{1}$ Jukka S Ylikoski, MD²
}

\begin{abstract}
YLIKOSKI ME, YLIKOSKI JS. Hearing loss and handicap of professional soldiers exposed to gunfire noise. Scand J Work Environ Health 1994;20:93-100.

OвJEctives - The aim of the study was to investigate the prevalence and degree of hearing loss and other disabling consequences of noise among professional soldiers.

MEthods - A cross-sectional audiometric survey was combined with a questionnaire study on disabilities in a stratified random sample of 699 army officers (mean age 39.8 years) with long-term exposure to gunfire noise.

Results - In 224 (32\%) officers, the hearing threshold was found to be $20 \mathrm{~dB}$ or less at all of the frequencies measured $(0.5,1,2,3,4,6$, and $8 \mathrm{kHz})$. Most of the $475(68 \%)$ subjects with hearing loss belonged to older age categories, but more than one-fourth $(26 \%)$ of the officers under 30 years of age had a hearing loss. Low frequencies were deteriorated in $110(16 \%)$ subjects. The average of the hearing threshold levels of the frequencies 2 and $4 \mathrm{kHz}$ exceeded $20 \mathrm{~dB}$ in $229(33 \%)$ officers. For $347(49.6 \%)$ subjects hearing was normal for their age. The degree of age-corrected hearing loss, especially at low frequencies, correlated highly significantly with exposure. Altogether $220(32 \%)$ men experienced tinnitus, $118(17 \%)$ of them continuously. Tinnitus was the most common among the men with severe or disabling hearing loss. Twenty-four (3.4\%) of 699 officers needed sound amplification in noisy environments.

Conclusions - The prevalence of hearing loss in the Finnish Defence Forces seems to have decreased, but a fairly large number of younger men still suffer considerable hearing loss and disabling tinnitus, although the use of hearing protectors has substantially increased during the past 15 years. Most of the subjects experienced communication difficulties in noisy environments.
\end{abstract}

KEY TERMS - audiometry, hearing handicap, impulse noise exposure, shooting noise, social hearing, tinnitus.

Exposure to high sound pressure levels (SPL) from weapon impulses is a universally recognized cause of noise-induced hearing loss (1-3). Among men who have been exposed to gunfire noise, the prevalence of hearing loss is as high as $40-60 \%(1,4$, 5 ). In the 1960 s, before hearing protectors were commonly used in the Finnish Defence Forces, about $60 \%$ of regular army personnel developed hearing loss (1). In a study of the United States Armed Forces in $1970-1975,20-30 \%$ of all personnel with two or more years of service and more than $50 \%$ of the men with 15 years of service in the combat arms branches had significant hearing loss (5). These data indicate that commonly used hearing protection may, in fact, still be insufficient. Small-volume earmuffs attenuate the peak SPL of rifle shot impulses (approximately $157 \mathrm{~dB}$ SPL) by $17 \mathrm{~dB}(6)$ and thus to the critical level of $140 \mathrm{~dB}$ SPL, but only if optimally fitted. On the other hand, the attenuation efficiency of hearing protectors has been shown to be very poor

Lappeenranta Regional Institute of Occupational Health, Lappeenranta, Finland.

2 Department of Otolaryngology, Kuopio University Hospital, Kuopio, Finland.

Reprint requests to: Dr M Ylikoski, Steniuksentie 24 A 7 , FIN-00320 Helsinki, Finland. against low-frequency impulse noise from large-caliber weapons (7).

With regard to impulse noise, the recommendations for damage risk criteria adopted from earlier studies and based on the equal energy principle are still controversial $(3,8-10)$. Part of the criticism originates from recent animal studies $(11,12)$, which show that the frequency-domain representation of the impulse noise spectrum must be given specific consideration in recommendations. However, other animal studies have revealed similar hearing thresholds after exposure to impulse noise and continuous noise of equivalent duration, frequency distribution, and energy, although the damage to cochlear hair cells has been greater after exposure to impulse noise (13).

A reliable way to evaluate the long-term health hazards of high-intensity impulse noise is to compare the occurrence and severity of hearing loss with reported levels of disabilities and handicap and to correlate the findings with the quantity and quality of exposure among persons exposed to impulse noise. For instance, tinnitus has been found to be more important than the level of noise exposure for predicting speech impairment and handicap due to hearing loss (14). From a practical viewpoint, communication difficulties as a consequence of noise-induced hearing loss are one of the most important indica- 
tors of handicap. Thus the relationship between hearing loss, impulse noise exposure, and social hearing are of interest.

The objectives of this study were to determine the occurrence and severity of hearing loss among staff officers and to relate the degree of hearing loss both to military noise exposure, taking into account recreational and steady-state noise exposures, and to the subjective assessment of the communication handicap in social situations and the handicap due to tinnitus.

\section{Subjects and methods}

The audiometric measurement records and questionnaire data on the shooting-noise exposure of 786 Finnish army officers were analyzed. The subjects formed an age-based stratified random sample of all regular army officers. Audiometric and questionnaire data were available for $718(90.9 \%)$ subjects. Nineteen were excluded because of incomplete questionnaires ( 9 cases) or because of apparent ear disease (10 cases, conductive hearing loss in nine and Meniere's disease in one). The age distribution of the excluded and included subjects was similar $(\mathrm{P}<0.5)$. Thus data from 699 officers were included in the analyses.

The mean age of the 699 subjects was 39.8 (median 41.0 , range $25-61$ ) years. There were 4 generals, 48 colonels, 99 majors, 184 captains, 154 senior lieutenants, and 190 lieutenants in the group.

\section{Hearing measurement records}

Since 1977 all employees in the Finnish Defence Forces have been regularly and repetitively screened with the screening audiometry method. The SPL has been $20 \mathrm{~dB}$, and the sound frequencies of $0.5-8.0$ $\mathrm{kHz}$ with one-half octave intervals, including $3.0 \mathrm{kHz}$ and $6.0 \mathrm{kHz}$, have been tested. In our study, screening audiometry was the only hearing test for 120 $(17 \%)$ subjects. The hearing threshold (HT) was determined for $363(52 \%)$ men with pure tone screening audiometry and for $216(31 \%)$ men with clinical pure tone audiometry. These two methods were administered for all of the test frequencies used with screening audiometry when any hearing loss was detected (ie, hearing threshold at least $20 \mathrm{~dB}$ or more at some of the frequencies in the screening audiometry). Pure tone audiometry was carried out at the Department of Ear, Nose and Throat of the Central Military Hospital in Helsinki. Screening and pure tone screening audiometry were performed in appropriate silent rooms according to the specifications of the ISO 6189 standard (15). Audiometers were calibrated according to the ISO R 389 standard (16). The procedures followed the specifications of the American Speech and Hearing Association (17). Pure-tone audiometry was conducted in a silent room (camera silenta) that conformed to the criteria of the American National Standards Institute (18). The hearing threshold was measured for both ears by pure-tone air-conducting signals. All of the tests were performed by nursing staff trained in audiometry and supervised by a qualified occupational health specialist or, in the case of pure-tone audiometry, by a qualified otolaryngologist. The hearing tests were not performed until sufficient time had elapsed $(16 \mathrm{~h}$ for pure-tone screening audiometry and $24 \mathrm{~h}$ for puretone audiometry) since the last noise exposure.

Audiometric test results were divided into five groups according to the results of the pure-tone audiometry or pure-tone screening audiometry of the worse ear as follows: (i) normal hearing: hearing threshold of $\leq 20 \mathrm{~dB}$ at all frequencies measured; (ii) slight hearing loss: hearing threshold of $>20 \mathrm{~dB}$ and $\leq 40 \mathrm{~dB}$ at some of the frequencies between 3.0 and $8.0 \mathrm{kHz}$ and $\leq 20 \mathrm{~dB}$ at all low frequencies $(0.5,1.0$, and $2.0 \mathrm{kHz}$ ); (iii) moderate hearing loss: hearing threshold of $41 \mathrm{~dB} \leq 64 \mathrm{~dB}$ at some of the frequencies from 3.0 to 8.0 and in the low-frequency range $<20 \mathrm{~dB}$; (iv) severe hearing loss: hearing threshold of $\geq 65 \mathrm{~dB}$ at some of the frequencies from 3.0 to $8.0 \mathrm{kHz}$ and in the low-frequency range $<20 \mathrm{~dB}$; (v) disabling hearing loss: hearing threshold of $>20 \mathrm{~dB}$ at some of the low frequencies.

The predicted deterioration of hearing with age (presbycusis) was taken into account by correcting the hearing threshold for age-related hearing loss according to ISO 7089 and ISO 1999 standards with five-year intervals $(19,20)$.

In connection with the tests, the subjects returned a completed questionnaire. The estimates of the subjects' exposure to weapon impulses were based on earlier studies of physical characteristics and energy levels of shots from different weapons. Exposure was calculated according to the equal energy principle $(9,21)$. Details were also requested of previous diseases, health complaints, and diseases and injuries possibly affecting hearing and verified by a physician. Questions about handicap because of hearing loss were included.

Audiometric formulas for assessing disability because of hearing loss according to the averages of hearing threshold levels (HTL) over particular frequencies have been recommended by the International Organization for Standardization (ISO) (20), Robinson et al (22), and Lafon (23). They were applied in the present study as follows:

\section{ISO (ISOFORM): [HTL at $0.5+\mathrm{HT}$ at $1.0+$ $\mathrm{HT}$ at $2.0 \mathrm{kHz} / 3$; \\ Robinson (RFORM): [HTL at $1.0+$ HT at $2.0+$ $\mathrm{HT}$ at $3.0 \mathrm{kHz}] / 3$;}

and

Lafon (LAFORM): [HTL at $2.0+\mathrm{HT}$ at $4.0 \mathrm{kHz}] / 2$.

Subjective experience of tinnitus was reported and classified as continuous when it occurred practically always and had a steady-state character. 
For a comparison of correlations between variables, Pearson's correlation coefficient ( $\mathrm{r}$ ) and the chi-square test were used. For testing the statistical significance of the differences in the mean values, Student's t-test was used.

\section{Results}

\section{Hearing threshold measurements}

Figure 1 shows the percentages of ears of the army officers with a hearing threshold in excess of 20,25 , 40 , and $65 \mathrm{~dB}$ at the test frequencies of $0.5-8.0 \mathrm{kHz}$. The threshold elevations were greater for the left ear than the right at $0.5-8.0 \mathrm{kHz}$, but the difference was not statistically significant (Student's t-test,
$0.05<\mathrm{P}<0.1)$. The hearing threshold was the most frequently elevated for both ears at $6.0 \mathrm{kHz}$. For both ears the measurements of thresholds exceeding 20 , 25,40 , and $65 \mathrm{~dB}$ at $2.0 \mathrm{kHz}$ were related to the age of the subjects (table 1).

At $2.0 \mathrm{kHz}$, thresholds higher than $20 \mathrm{~dB}$ were found in all of the age groups, but there was only one such case in the youngest age group (less than 30 years).

\section{Degree of hearing loss}

A total of 224 (32.0\%) subjects heard all test tones of $20 \mathrm{~dB}$ or less with both ears and were determined to have intact hearing. The hearing of $475(68.0 \%)$ subjects was considered impaired.

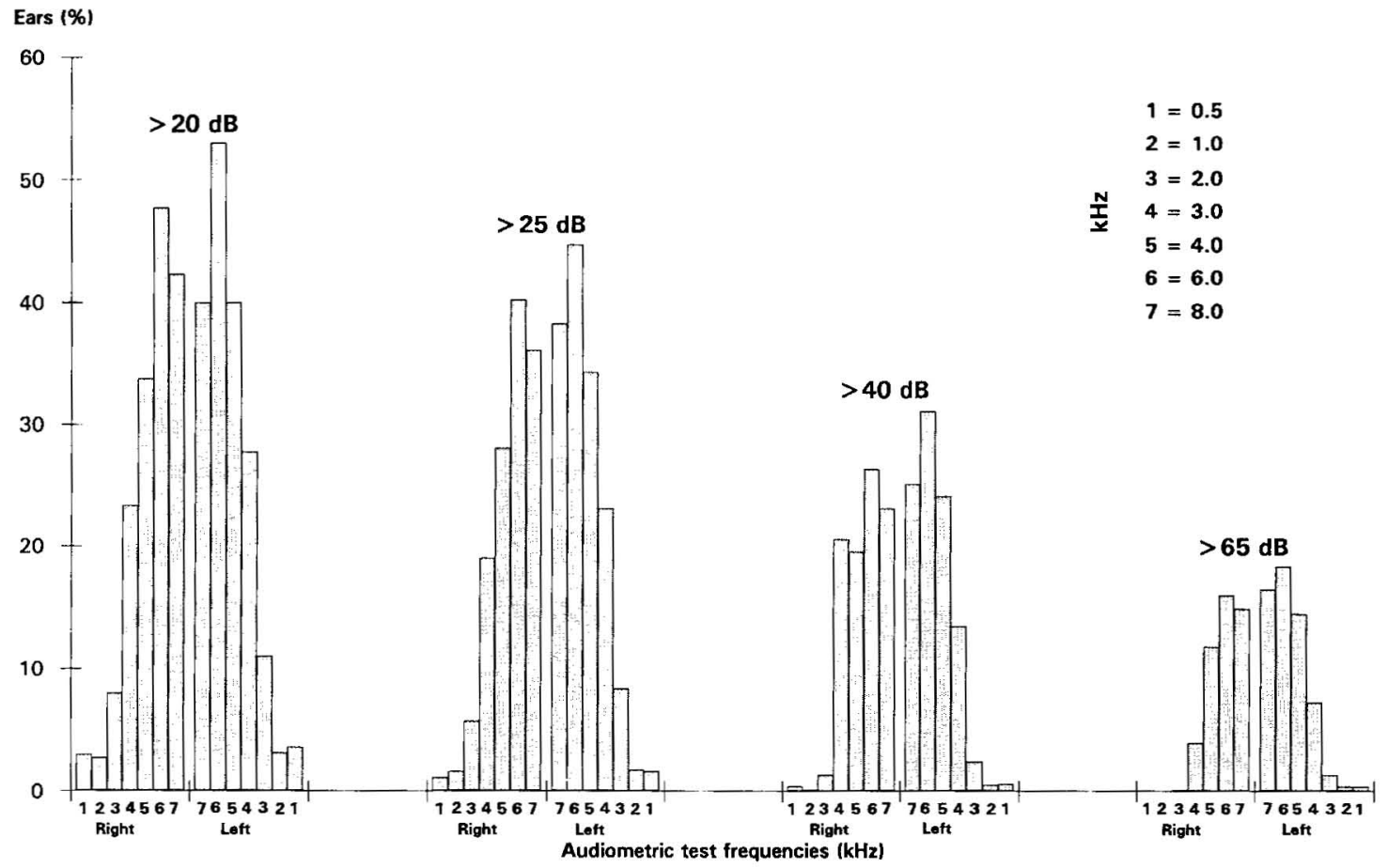

Figure 1. Distribution of the ears of the army officers by hearing thresholds at the given test frequencies, measured by screening audiometry, pure tone screening audiometry, and clinical audiometry.

Table 1. Ears of the army officers $(\mathrm{N}=699$ ) with elevated hearing thresholds $(\mathrm{HT})$ at $2 \mathrm{kHz}$ by age groups (as the percentage of all right or left ears, respectively).

\begin{tabular}{|c|c|c|c|c|c|c|c|c|c|}
\hline \multirow{3}{*}{ Age (years) ${ }^{a}$} & \multirow{3}{*}{$\begin{array}{c}\text { Number } \\
\text { of } \\
\text { officers }\end{array}$} & \multicolumn{8}{|c|}{ Hearing threshold } \\
\hline & & \multicolumn{2}{|c|}{$>20 \mathrm{~dB}$} & \multicolumn{2}{|c|}{$>25 \mathrm{~dB}$} & \multicolumn{2}{|c|}{$>40 \mathrm{~dB}$} & \multicolumn{2}{|c|}{$>65 \mathrm{~dB}$} \\
\hline & & Right & Left & Right & Left & Right & Left & Right & Left \\
\hline $\begin{array}{l}<30(27.0) \\
30-34(32.0) \\
35-39(37.0) \\
40-44(42.0) \\
45-49(46.0) \\
>50(52.0)\end{array}$ & $\begin{array}{r}110 \\
86 \\
90 \\
190 \\
158 \\
65\end{array}$ & $\begin{array}{r}0.0 \\
1.2 \\
5.6 \\
8.9 \\
17.4 \\
21.9\end{array}$ & $\begin{array}{r}0.9 \\
2.3 \\
4.8 \\
8.9 \\
17.1 \\
35.9\end{array}$ & $\begin{array}{r}0.0 \\
1.2 \\
3.3 \\
6.3 \\
7.6 \\
18.7\end{array}$ & $\begin{array}{r}0.0 \\
2.3 \\
3.3 \\
7.2 \\
12.7 \\
28.1\end{array}$ & $\begin{array}{r}0.0 \\
0.0 \\
0.0 \\
1.1 \\
2.5 \\
10.9\end{array}$ & $\begin{array}{r}0.0 \\
0.0 \\
0.0 \\
1.6 \\
4.4 \\
12.5\end{array}$ & $\begin{array}{l}0.0 \\
0.0 \\
0.0 \\
0.0 \\
0.0 \\
0.0\end{array}$ & $\begin{array}{l}0.0 \\
0.0 \\
0.0 \\
0.5 \\
1.3 \\
3.1\end{array}$ \\
\hline
\end{tabular}

a The median age is given in parentheses. 
The mean hearing threshold in the groups are presented separately for the left and right ears in figures 2 and 3 . One hundred and sixty-seven subjects (23.9\%) had slight, $87(12.4 \%)$ had moderate, 111 $(15.9 \%)$ had severe, and $110(15.7 \%)$ had disabling hearing loss. Among the disabled subjects, 45 (6.4\% of 699) had a mean hearing threshold level of more than $20 \mathrm{~dB}$ at frequencies $0.5,1$, and $2 \mathrm{kHz}$.
Age, rank and hearing loss

Of all the 475 cases of elevated hearing threshold, 155 were reclassified as a result of correction for agerelated hearing loss. Of the 110 subjects with disabling hearing loss, only three were reclassified. A total of $347(49.6 \%)$ of the 699 subjects had normal hearing for their age. The increase in age correlated highly significantly with the increase in the severity

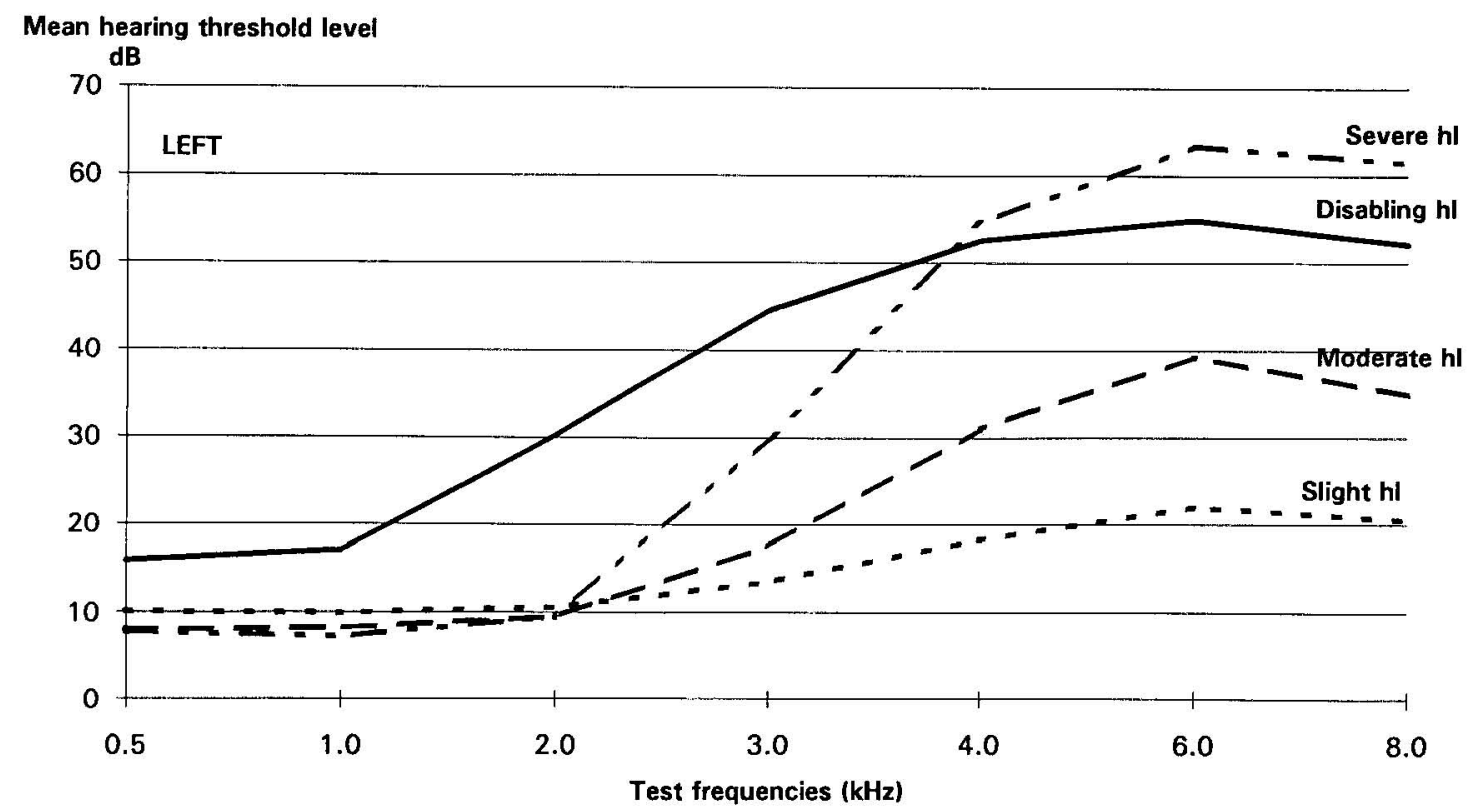

Figure 2. Average threshold levels for the left ears of 475 army officers with hearing loss (hl) of different severity.

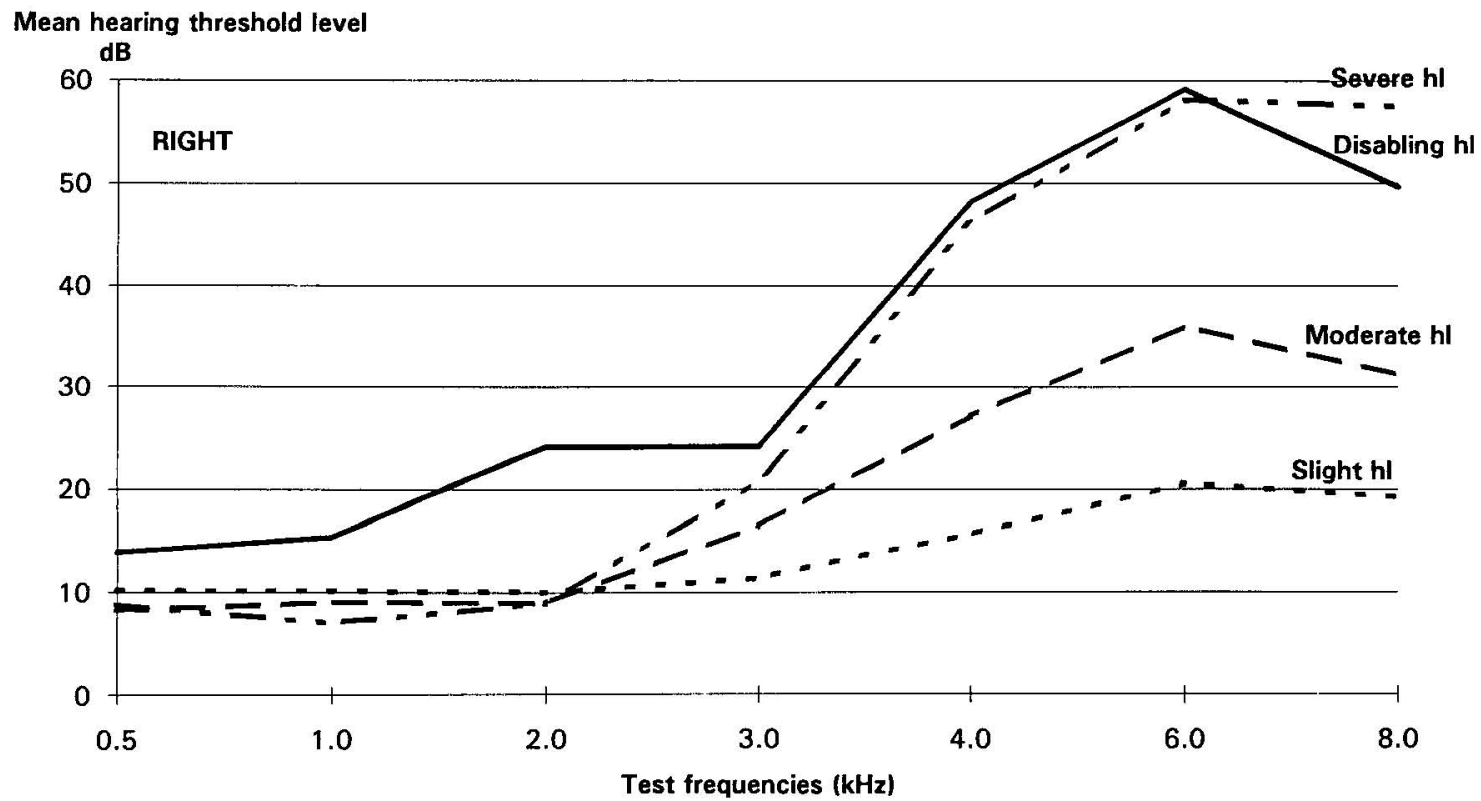

Figure 3. Average threshold levels for the right ears of 475 army officers with hearing loss (hl) of different severity. 
of hearing loss at frequencies of $0.5,1.0$, and $2.0 \mathrm{kHz}$ (chi square Pearson's r 153, degrees of freedom (df) $16, \mathrm{P}<0.0001)$. At frequencies of $3.0-6.0 \mathrm{kHz}$, the corresponding correlation was lower ( $\mathrm{r} 112$, df 16, $0.01<\mathrm{P}<0.05$ ). A comparison of hearing loss in relation to the rank of the officer showed that $25.8 \%$ of the academic lieutenants (mean age 28.8 years) suffered from hearing loss. The frequency of hearing loss was highest (54.0\%) among the colonels and generals (mean age 51.6 years). Exposure to steady noise ( $r$ 0.03) did not correlate with the degree of hearing loss. Hearing threshold did not correlate with the past history of ear diseases, family history of hearing loss, smoking or drinking habits, or exposure to organic solvents.

\section{Severity of hearing loss and exposure to gunfire noise}

The mean adjusted number of shots, fired by the subjects or in their presence, was related to the severity of age-corrected hearing loss. The highest correlation values, although rather low, were found between hearing loss at high frequencies and exposure to noise from small-caliber weapons ( $\mathrm{r} 0.21$ and 0.15 , $\mathrm{P}<0.001)$. Subjects with low-frequency hearing loss of more than $25 \mathrm{~dB}$ (independently of high-frequency hearing loss) had fired more shots (average 46940 ), and they had been exposed to impulse noise from more shots (average 237050 ) than the subjects without low-frequency hearing loss (means: 24150 shots personally fired and 150540 shots total exposure, $\mathrm{P}<0.005)$. After age-correction the rate ratio between the groups with and without low-frequency hearing loss was 2.65 according to the means of the numbers of personally fired shots and 3.25 according to the means of all shots. The total impulse noise exposure (all shots, including explosions) was compared with the severity of hearing loss with the weighting procedure according to the equal energy principle (9). The closest correlation was found between the total number of personally delivered shots and the degree of age-corrected hearing loss ( $\mathrm{r} 0.51$, $\mathrm{P}<0.0001$ ).

\section{Type of weapon causing hearing loss}

According to the questionnaire, $518(73.6 \%)$ subjects considered shooting with a particular weapon to be the major cause of their hearing loss. The rifle was reported as the primary cause by $53.7 \%$ and as the secondary cause by $32.5 \%$. Small-caliber cannons were implicated as the primary cause for $14.3 \%$. Altogether $9.2 \%$ reported large-caliber cannons as the main cause of hearing loss, and $19.1 \%$ blamed bazookas.

\section{Hearing loss and the use of hearing protectors}

The occurrence of hearing loss was compared with the use of hearing protectors reported in the ques- tionnaire (21). For both ears low negative correlations (ie, insufficient protection) were observed between frequent use of earplugs and hearing loss at low frequencies $(\mathrm{r}-0.10, \mathrm{P}<0.01)$ on the one hand and hearing loss at high frequencies $(r-0.15$, $\mathbf{P}<0.001$ ) on the other. For earmuffs the corresponding correlation coefficients were $-0.20(\mathrm{P}<0.001)$ for low-frequency hearing loss and $-0.28(\mathrm{P}<0.001)$ for high-frequency hearing loss.

\section{Occurrence of tinnitus}

The relationship between tinnitus and the severity of hearing loss is presented in table 2 . Of all of the subjects, $297(42.5 \%)$ reported that they experienced tinnitus occasionally or continuously. In 65 (9.3\%) continuous tinnitus had a high-pitched character. The occurrence of tinnitus correlated significantly with the total number of weapon impulses ( $\mathrm{r} 0.27$, $\mathrm{P}<0.001)$. There was a higher correlation between tinnitus and exposure to noise from small-caliber weapons ( $\mathrm{r} 0.26, \mathrm{P}<0.001)$ than between tinnitus and exposure to noise from large-caliber weapons ( $\mathrm{r} 0.1, \mathrm{P}<0.05$ ). A frequent use of hearing protectors correlated negatively with the presence of tinnitus $(\mathrm{r}-0.17, \mathrm{P}<0.001)$.

\section{Hearing handicap}

The subjects' assessments of their handicap because of hearing loss are described in table 3. Noisy environments caused the greatest difficulties, and they increased in parallel with an increasing severity of hearing loss (chi-square r 228, df 12, $\mathrm{P}<0.0001$ ). The total exposure to shooting noise also correlated with difficulties to hear in noisy environments (Pearson's r $0.33, \mathrm{P}<0.001$ ). Of the whole series of 699 subjects, $24(3.4 \%)$ reported that they always needed sound amplification in noisy environments. Nine of these men had severe hearing loss, and for 12 the loss was disabling. A comparison of the handicap data (table 3) with the hearing disability criteria of ISO (20) failed to reveal any correlation ( $\mathrm{r}-0.06$, $0.05<\mathrm{P}<0.1)$ (table 4$)$. Forty-five $(6.4 \%)$ subjects had an average hearing threshold level of more than $20 \mathrm{~dB}$ according to ISOFORM. For RFORM and

Table 2. Severity of hearing loss and occurrence of tinnitus $(\%)$ among the army officers $(\mathrm{N}=669)$.

\begin{tabular}{lcrrr}
\hline & \multirow{2}{*}{$\begin{array}{c}\text { Number } \\
\text { of } \\
\text { Hearing loss }\end{array}$} & \multicolumn{4}{c}{ Tinnitus (\%) } \\
\cline { 3 - 5 } & officers & $\begin{array}{c}\text { Occa- } \\
\text { sional }\end{array}$ & $\begin{array}{c}\text { Con- } \\
\text { tinuous }\end{array}$ & Both \\
\hline $\begin{array}{l}\text { None } \\
\text { (normal hearing) }\end{array}$ & 224 & 33.2 & 2.2 & 35.4 \\
$\begin{array}{l}\text { Slight } \\
\text { and moderate }\end{array}$ & 254 & 31.0 & 2.7 & 33.7 \\
$\begin{array}{l}\text { Severe } \\
\text { Disabling }\end{array}$ & 111 & 31.5 & 19.8 & 51.4 \\
\hline Total & 110 & 42.7 & 25.5 & 68.2 \\
\hline
\end{tabular}


Table 3. Self-assessed ability of the 699 army officers to hear and manage in different situations (as a percentage of answers) in relation to measured hearing loss (presented as Pearson's correlation coefficient and significance values).

\begin{tabular}{|c|c|c|c|c|c|}
\hline \multirow[b]{2}{*}{ Ability to hear } & \multicolumn{5}{|c|}{ Situation } \\
\hline & $\begin{array}{c}\text { Face to face } \\
(\%)\end{array}$ & $\begin{array}{c}\text { Group } \\
(\%)\end{array}$ & $\begin{array}{c}\text { Noisy environment } \\
(\%)\end{array}$ & $\begin{array}{l}\text { Phone } \\
(\%)\end{array}$ & $\begin{array}{c}\text { Theater or } \\
\text { seminars }(\%)\end{array}$ \\
\hline $\begin{array}{l}\text { As well as most people } \\
\text { Difficulties - some words } \\
\text { Difficulties - great } \\
\text { Amplification needed }\end{array}$ & $\begin{array}{r}86.4 \\
13.2 \\
0.4 \\
0.0\end{array}$ & $\begin{array}{r}68.8 \\
26.4 \\
4.7 \\
0.1\end{array}$ & $\begin{array}{r}42.7 \\
36.8 \\
17.0 \\
3.4\end{array}$ & $\begin{array}{r}75.6 \\
20.2 \\
1.6 \\
2.6\end{array}$ & $\begin{array}{r}73.8 \\
23.5 \\
2.4 \\
0.3\end{array}$ \\
\hline Total & 100.0 & 100.0 & 100.0 & 100.0 & 100.0 \\
\hline $\begin{array}{l}\text { Correlation } \\
\text { Significance }\end{array}$ & $\begin{array}{c}0.28 \\
P<0.001\end{array}$ & $\begin{array}{c}0.50 \\
P<0.001\end{array}$ & $\begin{array}{c}0.55 \\
P<0.001\end{array}$ & $\begin{array}{c}0.38 \\
P<0.001\end{array}$ & $\begin{array}{c}0.50 \\
P<0.001\end{array}$ \\
\hline
\end{tabular}

Table 4. Comparison of hearing disability according to the disability criteria of the International Organization for Standardization (ISOFORM), Robinson (RFORM) and Lafon (LAFORM) with the severity of hearing loss and the officers' own assessments of their social hearing ability (Pearson's correlation coefficient and significance).

\begin{tabular}{lcc}
\hline & \multicolumn{2}{c}{ Correlation of formulas } \\
\cline { 2 - 3 } Formula & $\begin{array}{c}\text { Severity of } \\
\text { hearing loss }\end{array}$ & $\begin{array}{c}\text { Difficulties of } \\
\text { communication } \\
\text { in noisy } \\
\text { environments }\end{array}$ \\
\hline $\begin{array}{l}\text { ISOFORM } \\
\text { Correlation } \\
\text { Significance }\end{array}$ & -0.13 & -0.06 \\
RFORM & $\mathrm{P}<0.01$ & $\mathrm{P}<0.1$ \\
$\begin{array}{l}\text { Correlation } \\
\text { Significance }\end{array}$ & 0.23 & 0.24 \\
$\begin{array}{c}\text { LAFORM } \\
\text { Correlation } \\
\text { Significance }\end{array}$ & $\mathrm{P}<0.001$ & $\mathrm{P}<0.001$ \\
\hline & $\mathrm{P}<0.001$ & $\mathrm{P}<0.001$ \\
\hline
\end{tabular}

LAFORM the corresponding numbers were 104 $(14.9 \%)$ and $229(32.8 \%)$, respectively. The correlation between the subjects' assessment of their hearing loss handicap and their hearing disability according to LAFORM was the highest (table 4).

According to the questionnaire, 174 (24.9\%) of the 699 subjects had, at times, doubted their ability to perform their duties because of hearing difficulties and six subjects had often done so. Of these $180 \mathrm{men}$, $132(73.3 \%)$ had a hearing loss of at least moderate degree. Compared with subjects with intact hearing, the difference was almost significant $(0.001<$ $\mathrm{P}<0.01)$. One hundred and forty-seven $(20.5 \%)$ men stated that they avoided demanding tasks for fear of failure because of hearing loss; four of them said that they did this regularly. All 147 had moderate or more severe hearing loss.

\section{Discussion}

In our study we attempted to describe the occurrence, severity, and consequences of hearing loss in a rather homogeneous group of men, exposed similarly to gunfire noise. Industrial and recreational noise exposures, family history of hearing loss, incidence of trauma (eg, head trauma), chemical exposures, and habitual exposure to smoking, alcohol and coffee were infrequent and evenly distributed among the subjects. Only age and degree of exposure to military gunfire noise differed significantly between the groups of officers with different degrees of hearing loss. However, errors in the recollection of exposure and inconsistencies in the subjective assessment of experiences must be taken into account when our results are evaluated.

In this stratified random sample of army officers, hearing loss was found in $68 \%$ of the men. More than one-quarter of these men belonged to the youngest age category. The degree of hearing loss, especially at low frequencies, correlated highly significantly with exposure. It seems that, in army officers, hearing loss develops rather early in the career in parallel with the magnitude of exposure to gunfire noise. Earlier studies of the Finnish Defence Forces have shown a high prevalence of hearing loss among army staff and a high incidence of hearing loss in conscripts $(1,4,24)$. In a study based on data from pure-tone audiometry, Salmivalli (1) found age-corrected hearing loss in 33\% of army staff after five years of military service and in $69 \%$ after 20 years of service. In the United States Army, 20$30 \%$ of the personnel with more than two years of service and about $50 \%$ of the personnel with more than 15 years of service had suffered significant hearing loss (5). In our study age-corrected hearing loss occurred in $50.4 \%$ of the men, and this value is lower than the $67 \%$ reported by Salmivalli (1). However, the study of Salmivalli (1) was not performed on a random sample; instead it used a selected group of men with a high level of exposure to gunfire noise. Hearing loss seems to occur clearly more frequently in army officers than in the middle-aged male (35-64 years) populations of Finland or the United Kingdom, where prevalences of hearing loss vary between 6 and $11 \%$, according to some earlier studies $(25-27)$.

The high prevalence of hearing loss among military officers may be related to the insufficient use 
of hearing protectors in earlier years, and the fact that the peak SPL of shot impulses ranges from 155 to $185 \mathrm{~dB}(1,12,28)$. In the Finnish Defence Forces, earmuffs came into common use in 1977. Most of the officers in our study had worn earmuffs. Nevertheless, hearing loss was very common among them.

Measured hearing loss from exposure to impulse noise has been shown to be greater than the loss predicted by the application of the equal energy principle (9). The equal energy principle seems to be even less applicable to low-frequency impulse noise than to high-frequency impulse noise (29). This possibility may reflect damage in the function of the cochlear amplifier, an active process, through which the outer hair cells modulate the oscillations of the basilar membrane $(30-32)$. One sign of impaired amplifier function and sensitivity of the ear may be a decreased ability to discriminate speech in noisy environments (33). This was a common complaint of our subjects, even of those who belonged to younger age categories and had only a slight or moderate hearing loss, but a heavy history of exposure to gunfire noise.

Among subjects with hearing loss, the proportions affected by tinnitus have varied from $4.6 \%$ (34) to $30 \%$ (35). Salmivalli (1) found that $15.7 \%$ of military personnel with normal hearing and $56.0 \%$ with severe hearing loss experienced tinnitus (1). In our study, the overall occurrence of experienced tinnitus was $42.5 \%$, and the prevalence was highest (68\%) among the subjects with severe or disabling hearing loss. Of industrial workers claiming compensation for hearing loss, 58\% suffered from tinnitus, which was particularly frequent among workers exposed to impulse noise (36). In our study, the presence and severity of tinnitus correlated highly significantly both with the degree of hearing loss and with exposure to gunfire noise, especially with that from smallcaliber weapons.

Our results indicate that a fairly large proportion of military officers suffer hearing loss that has developed during their military service in spite of an increased use of hearing protectors. Optimal hearing protection must be used from the very beginning of a person's military career, because noise-induced hearing loss occurred already in a large number of the youngest officers.

In the present study, social hearing was determined from the subjective assessment of hearing difficulties in certain situations, and most of the officers who reported communication difficulties and had hearing loss had difficulties, especially in noisy environments. This problem should be taken into account when the rehabilitation of persons with hearing loss is planned. Experienced tinnitus is also commonly reported by army officers exposed to gunfire noise, and further studies are needed on the annoying and disabling effects of this complaint.

\section{References}

1. Salmivalli A. Acoustic trauma in regular army personnel: clinical and audiological study. Acta Otolaryngol Suppl (Stockh) 1967;222:1-85.

2. Coles RRA, Carinther GR, Hodge DC, Rice CG. Hazardous exposure to impulse noise. J Acoust Soc Am 1968;43:336-46.

3. Johnson DL, Riffle C. Effects of gunfire on hearing level for selected individuals of the inter-industry noise study. J Acoust Soc Am 1982;72:1311-14.

4. Riihikangas P, Anttonen H, Hassi J, Sorri M. Hearing loss and impulse noise during military service. Scand Audiol Suppl 1980;12:292-97.

5. Walden B, Prosek R, Worthington D. The prevalence of hearing loss within selected US Army branches. Washington, DC: Walter Reed Army Medical Center, 1975. (Technical report; IAO 4745.)

6. Ylikoski JS, Pekkarinen JO, Starck JP. The efficiency of earmuffs against impulse noise from firearms. Scand Audiol 1987;16:361-64.

7. Pekkarinen JO, Starck JP, Ylikoski JS. Hearing protection against high level shooting impulses in relation to hearing damage criteria. J Acoust Soc Am 1992;91:196-202.

8. Coles RRA, Rice CG. Towards a criterion for impulse noise in industry. Ann Occup Hyg 1970;13:43-52.

9. Atherley GRC. Noise-induced hearing loss: the energy principle for recurrent impact noise and noise exposure close to the recommended limits. Ann Occup Hyg 1973;16:183-92.

10. Ward WD, ed. Proposed damage risk criterion for impulse noise (gunfire). Washington, DC: Committee of Hearing, Bioacoustics and Biomechanics, National Academy of Sciences, National Research Council, 1968. (Report of a working group; no 57.)

11. Price GR, Wansack S. Hazard from an intense midrange impulse. J Acoust Soc Am 1989;86:2185-91.

12. Hamernik RP, Ahroon WA, Hsueh KD. The energy spectrum of an impulse: its relation to hearing loss. J Acoust Soc Am 1991;90:197-202.

13. Nilsson P, Rydmarker S, Grenner J. Impulse noise and continuous noise of equivalent frequency spectrum and total sound energy. Acta Otolaryngol Suppl (Stockh) 1987;441:45-58.

14. Neuberger M, Korpert K, Raber A, Schwetz F, Bauer $P$. Hearing loss from industrial noise, head injury and ear disease: a multivariate analysis on audiometric examinations of 110647 workers. Audiology 1992;31: $45-57$.

15. International Organization for Standardization (ISO). Pure tone air conduction threshold audiometry for hearing conservation purposes. Geneva: ISO, 1983. (ISO 6189 acoustics.)

16. International Organization for Standardization (ISO). Standard reference zero for the calibration of pure-tone audiometers. Geneva: ISO, 1975. (ISO R 389 acoustics.)

17. Carhart R, Jerger J. Preferred method for clinical determination of pure tone thresholds. J Speech Hear Disord 1959;24:330—45.

18. American National Standards Institute (ANSI). American standard criteria for permissible ambient noise during audiometric testing. New York, NY: ANSI, 1977. (ANSI 53:1-1960).

19. International Organization for Standardization (ISO). Threshold of hearing by air conduction as a function of age and sex for otologically normal persons. Geneva: ISO, 1984. (ISO 7089 Acoustics).

20. International Organization for Standardization (ISO). Determination of occupational noise exposure and estimation of noise induced hearing impairment. Geneva: ISO, 1985. (ISO 1999 Acoustics).

21. Ylikoski ME. Prolonged exposure to gunfire noise 
among professional soldiers. Scand J Work Environ Health 1994;20:87-92.

22. Robinson DW, Wilkins PA, Thyer NJ, Lawes JF. Auditory impairment and onset of disability and handicap in noise-induced hearing loss. Southampton: University of Southampton, 1984. (ISVR technical report; no 126.$)$

23. Lafon J-C. Measurement of hearing level in occupational noise-induced hearing loss. Audiology 1981;20: $79-85$.

24. Ylikoski JS. Acute acoustic trauma in Finnish conscripts. Scand Audiol 1989;18:161-5.

25. Era P. Sensory, psychomotor, and motor functions in men of different ages. Scand J Soc Med Suppl 1987; 39:1-77.

26. Rahko T, Karma P, Pitkäjärvi T, Nurminen H, Kataja $M$. The prevalence of handicapping hearing loss in a middle-aged population in Finland. Arch Otorhinololaryngol $1988 ; 245: 57-9$.

27. D'Souza MF, Irwing LM, Travelyan HT. Deafness in middle age - how big is the problem? J R Coll Gen Pract 1975;25:472-8.

28. Anttonen H, Sorri M, Hassi J, Riihikangas P. The impulse noise exposure during military service. Scand Audiol Suppl 1980;12:17-24.

29. Dancer A, Grateau P, Cabanis A, Barnabe G, Gagnin $\mathrm{G}$, Vaillant T, et al. Effectiveness of earplugs in high- intensity impulse noise. J Acoust Soc Am 1992;91: 1677-88.

30. Saunders JC, Cohen YE, Szymco YM. The structural and functional consequences of acoustic injury in the cochlea and peripheral auditory system: a five year update. J Acoust Soc Am 1991;90:136-46.

31. Brownell WE, Bader CR, Bertrand D, de Ribaupierre Y. Evoked mechanical responses of isolated cochlear outer hair cells. Science 1985;227:194-6.

32. Neely ST, Kim DO. A model for active elements in cochlear biomechanics. J Acoust Soc Am 1986;79: 1472 - 80.

33. Zenner H-P, Zimmerman U, Schmitt U. Reversible contraction of isolated mammalian cochlear hair cells. Hear Res 1985; 18:127-33.

34. Ehrman G. Zum Problem der Ohrgeräusche bei der Lärmschwerhörigkeit [dissertation]. Jena: University of Jena, 1966.

35. Chadwick DL. The behavior of the pathological ear in noise. Acta Oto Rhino Laryngol Belg 1971;25: $113-7$.

36. Alberti PW. Tinnitus in occupational hearing loss: nosological aspects. J Otolaryngol 1987;16:34-5.

Received for publication: 3 June 1993 